\title{
NEGOCIAÇÃo PROCESSUAL ATÍPICA NO ÂMBITO DO PROCESSO COLETIVO
}

\author{
ATYPICAL PROCESSUAL NEGOTIATION WITHIN THE COLLECTIVE \\ PROCESS
}

\author{
Lourenço de Miranda Freire Neto ${ }^{1}$ \\ Fernando Gustavo Knoerr ${ }^{2}$ \\ Marina Marinho Davino de Medeiros ${ }^{3}$
}

\section{RESUMO}

O estudo examina como se dá a aplicação dos negócios jurídicos processuais atípicos ao processo coletivo e, desse modo, se busca entender a forma mais efetiva de promover a negociação no âmbito da tutela de direitos metaindividuais a considerar os limites formais aos acordos processuais e, por fim, se defende a possibilidade de relativização de tais limites a fim de alcançar a melhor operacionalidade do processo e, em decorrência disso, as garantias do devido processo legal através da valorização da autonomia da vontade e, consequentemente, da concretização do princípio do autorregramento da vontade no processo.

Palavras-chave: Direito Processual Coletivo. Negócios jurídicos processuais. Legitimidade extraordinária. Autonomia privada. Devido processo legal.

\begin{abstract}
The study examines the application of atypical procedural legal agreement to the collective process and, thus seeks, to understand the most effective way to promote negotiation within the framework of meta-individual rights to consider the formal limits to procedural agreements and, therefore, finally, the possibility of relativization of such limits is advocated in order to achieve

\footnotetext{
${ }^{2}$ Advogado e Professor. Doutorando em Direito Político e Econômico pela Universidade Presbiteriana Mackenzie. Mestre em Direito pela Universidade Católica de Pernambuco. Bacharel em Direito pela Universidade Federal da Paraíba. Professor da Universidade Federal da Paraíba - licenciado para tratar de assuntos particulares. Professor Assistente e Coordenador de Educação Continuada na Universidade Presbiteriana Mackenzie. Atua nas áreas de direito médico, direito da saúde (seguridade social), direito constitucional, direito civil, direito processual civil e prática jurídica civil. Integrante do Conselho Editorial da Juruá Editora. Parecerista da Revista Internacional de Direito do Conselho Internacional de Estudos Contemporâneos em Pós-Graduação. Membro do Comitê de Ética em Pesquisa do Centro de Ciências Médicas da Universidade Federal da Paraíba. Foi Presidente da Comissão de Direito Médico-Hospitalar e Planos de Saúde (2013-2016) e Ouvidor-Geral Adjunto (2018) da Ordem dos Advogados do Brasil Seccional da Paraíba.

2 Doutor e Mestre em Direito do Estado pela Universidade Federal do Paraná. Bacharel em Direito pela Universidade Federal do Paraná. Ex-Procurador Federal. Professor de Direito Administrativo da Escola da Magistratura do Paraná e da Fundação Escola do Ministério Público do Paraná / FEMPAR. É Professor Permanente do Programa de Mestrado em Direito Empresarial e Cidadania do UNICURITIBA. Realizou estágio Pós- Doutoral na Universidade de Coimbra, Portugal.

${ }^{3}$ Advogada inscrita na OAB/PB. Pós-graduanda no Curso de Preparação à Magistratura com Residência Judicial e Especialização em Prática Judicante em Prática Judicante pela Escola Superior de Magistratura. Bacharel em Direito pela Universidade Federal da Paraíba.
} 
the best operability of the process and, as a result, the guarantees of due process of law through, the valorization of the autonomy of the will and, consequently, the implementation of the principle of self-willing in the process.

Keywords: Collective Procedural Law. Procedural legal agreement. Extraordinary legitimacy. Private autonomy. Due process of law.

\section{Introdução}

O presente artigo tem por objeto o estudo da celebração de negócios jurídicos processuais atípicos no âmbito do processo coletivo. Entre as inovações trazidas pelo Novo Código de Processo Civil (Lei n 13.105 , de 16 de março de 2015), a negociação processual foi uma delas, que trata da possibilidade de os sujeitos do processo regularem seus próprios comportamentos ou a forma como a norma processual se aplicará à relação jurídica ali discutida.

Ocorre que, o principal desafio é o de aplicar tal instituto quando se está a tratar de direitos coletivos, que precisam de tutela específica. Neste sentido, surge a negociação atípica como possibilidade de concretização do princípio ao autorregramento da vontade no processo, até porque, nessa modalidade, o que se busca discutir não é o objeto litigioso do processo, mas sim o próprio processo, de modo que suas regras sirvam à vontade das partes.

Para que a negociação ocorra de forma legítima, é imprescindível que respeite o princípio da boa-fé objetiva e, consequentemente, que se cumpram seus deveres anexos. Por outro lado, para que os negócios atípicos se desenvolvam legitimamente, é preciso que respeitem a cláusula geral de negociação do art. 190, o momento ideal de celebração e os requisitos de validade.

Contudo, ainda que existam limites à negociação atípica coletiva devido às normas cogentes, não se justifica que tais impedimentos dificultem a própria operacionalidade do processo. Desse modo, o problema emerge quando se considera que os requisitos formais impedem a própria tutela do direito ali pretendido.

Ante a escassez doutrinária acerca do tema, o presente estudo averigua a possibilidade de realização de negócios jurídicos processuais atípicos no âmbito do processo coletivo através da transposição dos limites estabelecidos à negociação coletiva de modo que os impactos à operacionalidade tanto do processo quanto da própria negociação sejam diminuídos, buscando a concretização do devido processo legal e a efetivação da justiça pelas coletividades, priorizando a autonomia das partes.

De início, se fez uma análise interdisciplinar acerca das noções basilares ao desenvolvimento válido dos negócios jurídicos processuais. Em seguida, para se entender melhor o novo paradigma de celebração dos negócios jurídicos processuais, foram comparados 
o CPC de 2015 e o de 1973 e, posteriormente, analisada a possibilidade de representação processual e os fundamentos da tutela coletiva de direitos que permitem a aplicabilidade dos acordos processuais quando da proteção aos direitos coletivos.

Por fim, foram discutidos os danos às garantias pretendidas com a propositura da ação em virtude das limitações formais à negociação atípica nas causas de natureza coletiva, que deveria ser, na verdade, instrumento de democratização do processo.

\section{Noções introdutórias acerca dos negócios jurídicos processuais e a cláusula geral de negociação do art. 190 do CPC}

O instituto da negociação jurídica processual foi introduzido no ordenamento jurídico brasileiro pelo Novo Código de Processo Civil. Antes dele, o CPC de 1973 apenas previa de forma elementar a possibilidade de acordos de cunho procedimental, que não se aproximavam ao que hoje é disposto pelos artigos 190 e 191 do Novo CPC.

Antes de mais nada, vale lembrar que os negócios jurídicos processuais compõem a teoria dos atos jurídicos que se dividem em atos jurídicos stricto sensu, com efeitos predeterminados pela lei e em negócios jurídicos, nos quais prepondera a autonomia da vontade das partes. (MEDINA, 2017, p. 128)

É justamente por esta característica que os negócios processuais se enquadram na categoria de atos dispositivos, uma vez que são atos pelos quais as partes livremente regulam suas posições jurídicas no processo (CÂMARA, 2017, p. 116).

Portanto, o negócio jurídico processual é o fato jurídico voluntário, em cujo suporte fático se reconhece ao sujeito o poder de regular, dentro dos limites fixados no próprio ordenamento jurídicos, certas situações jurídicas processuais ou alterar o procedimento. (DIDIER; NOGUEIRA, 2012, p. 59-60)

O texto legal elenca requisitos para a realização destas convenções: o processo deve versar sobre direitos que admitam autocomposição e as partes devem ser capazes. Atendidas tais prerrogativas, podem os sujeitos da relação jurídica estipular mudanças no procedimento a fim de ajustá-lo às especificidades da causa.

O direito em litígio pode ser indisponível, mas admitir solução por autocomposição (DIDIER Jr., 2017, p. 438) e é esse o raciocínio utilizado para se permitir, por exemplo, a negociação processual atípica quando da tutela de direitos coletivos que - por sua natureza são indisponíveis. (Enunciado 58, FPPC) 
Além do mais, a validade desses acordos é controlada pelo juiz da causa que, de ofício ou a requerimento das partes, observa a ocorrência de nulidades, abusividade ou onerosidade excessiva nos negócios realizados.

$\mathrm{Na}$ verdade, o artigo 190 do CPC criou o que a doutrina chama de "cláusula geral de negociação processual", de modo que agora as partes podem convencionar sobre dois objetos: as situações processuais e o procedimento, ambos para a viabilização de suas pretensões.

Como o objetivo é o de viabilizar a pretensão jurídica das partes, para que a tutela de direitos se dê de modo efetivo, é possível àquelas convencionar acerca de suas próprias posições, ou seja, sobre seus ônus, poderes, faculdades e deveres processuais. (NEVES, 2017, p. 327).

Por outro lado, não é permitido às partes dispor sobre a posição processual do juiz (Enunciado n. 36, ENFAM), somente sendo possível o negócio quando o próprio titular daquela posição pretende convencionar sobre ela.

O artigo 190 do CPC, ao estabelecer a cláusula geral de negociação processual, por consequência, cria o princípio do respeito ao autorregramento da vontade no processo. Essa regra diz respeito à necessidade de se respeitar o exercício da autonomia privada das partes no âmbito do processo e dos acordos processuais.

Até porque, por ser o negócio processual decorrente da própria vontade das partes, não deve ele se sujeitar a um juízo de conveniência pelo juiz, mas somente a um juízo de validade, uma vez que a eficácia do negócio celebrado dependerá unicamente disso. Inclusive, a regra é a dispensa da necessidade de homologação judicial do negócio processual (DIDIER Jr., 2017, p. 428) o que legitima ainda mais o privilégio dado pela lei à autonomia dos sujeitos.

Os negócios processuais, de forma geral, se subdividem em unilaterais, ou seja, decorrentes da manifestação de vontade de apenas uma das partes e bilaterais, frutos da convenção entre duas vontades. Estes últimos, de acordo com Didier, se subdividem em contratos, se os interesses são contrapostos e acordos se os interesses são convergentes. (DIDIER Jr., 2017, p. 426)

Além destes, existem os plurilaterais que abrangem a vontade de mais de dois sujeitos do processo e que podem ser divididos em negócios típicos, ou seja, estipulados em lei e atípicos que, mesmo não tendo forma disciplinada diretamente pelo ordenamento, não são vedados.

Também existem os negócios expressos, nos quais as partes estipulam de fato sobre o objeto do negócio (como o foro de eleição) e os tácitos, nos quais, implicitamente, por comportamentos comissivos ou omissivos de alguma(s) parte(s) se entende pela aceitação ou 
não ao negócio ora celebrado (como o consentimento tácito do cônjuge para a propositura de ação de direito real imobiliário).

Quanto ao momento, os negócios podem ser celebrados tanto no curso do processo quanto pré-processualmente, situação em que inexiste um processo judicial, mas as partes já convencionaram acerca de possíveis situações jurídicas futuras.

Ainda que, geralmente, seja dispensada a homologação judicial aos negócios processuais, excepcionalmente, tal pronunciamento é necessário quando se trata do controle de validade. Mesmo com a regulação da autonomia privada das partes nesses casos, o acordo procedimental por elas celebrado é eficaz independentemente de qualquer ato homologatório judicial. (NEVES, 2017)

Os negócios atípicos disciplinam situações jurídicas processuais (ônus, faculdades, deveres e poderes) e a parte final do art. 190 do CPC privilegia justamente a atipicidade da negociação, privilegiando o princípio ao autorregramento da vontade no processo. Considerando isso, a finalidade do negócio atípico é justamente a de convencionar acerca do próprio procedimento e não sobre o objeto litigioso do processo.

A função dos negócios processuais é a de possibilitar às partes dispor acerca de suas próprias posições processuais dentro dos limites estabelecidos pela lei. (CÂMARA, 2017, p. 116-117). Ora, por provocarem mudanças ao procedimento a fim de ajustá-lo às especificidades da causa, é lógico que negócios somente podem ocorrer quando respeitarem a cláusula geral de negociação.

Tal cláusula estabelece as regras gerais da negociação processual, de modo que: 1) o direito objeto de negócio deve admitir autocomposição; 2) as partes devem ser capazes, sendo vedada a celebração pelos incapazes ainda que representados ou assistidos; 3) os negócios processuais podem ocorrer antes ou durante o processo; 4) as partes somente estipulam sobre suas próprias posições processuais; 5) o controle feito pelo juiz diz respeito tão somente à validade do negócio e não à sua eficácia.

Primeiramente, a ordem pública processual deve ser respeitada de modo que tudo aquilo que estiver fora do alcance negocial das partes com relação ao plano do processo não pode ser objeto de negócio processual (BUENO, 2018, p. 339), reforçando ainda mais o respeito às normas cogentes por serem essas de caráter público.

O que os negócios processuais proporcionam é a flexibilização procedimental e tais regras permitem quase que a "construção" de um procedimento adequado ao caso concreto, com a intervenção do órgão judiciário e das partes. (MARINONI; ARENHART; MITIDEIRO, 2017, p. 31) 
É justamente por isso que se pretende, com o direito ao autorregramento da vontade no processo, o respeito ao direito fundamental à liberdade em suas quatro zonas: de negociação (previamente à realização do negócio), de criação (com a possibilidade de estipulação de diversos tipos de negócios atípicos), de estipulação (que escolhe e delimita o conteúdo do negócio) e de vinculação (que permite às partes celebrar ou não o negócio). (DIDIER Jr. apud ASCENSÃO, 1999, p. 78-80)

Em suma, considerando que as regras procedimentais não podem inviabilizar a própria tutela do direito material do caso concreto, se pretende, através dos acordos processuais, a concretização das técnicas processuais em cada caso, evidenciando a possibilidade da construção da ação ou do procedimento conforme as necessidades substanciais carentes de tutela e as particularidades do caso concreto. (MARINONI; ARENHART; MITIDEIRO, 2017, p. 31)

\section{O novo paradigma de celebração de negócios jurídicos processuais e a legitimidade à negociação processual coletiva}

É certo que o CPC de 2015 inaugurou um novo paradigma de celebração de negócios processuais, que tem por finalidade o respeito ao autorregramento da vontade através da ampliação dos limites da autonomia privada, promovendo a democratização do processo em razão da garantia do princípio do devido processo legal. Até porque, um processo que limite injustificadamente o exercício da liberdade não pode ser considerado um processo devido. (DIDIER Jr., 2018, p. 19)

Fica claro que, com essas novas disposições, o modelo cooperativo e comparticipativo de processo (THEODORO Jr., 2015, p. 69), pautado na boa-fé e no respeito ao devido processo legal permitem que, por intermédio dos negócios processuais, haja uma modulação do procedimento às especificidades de cada causa em respeito à autonomia dos próprios sujeitos processuais.

Assim, o processo judicial inaugura um novo paradigma na medida em que há a transformação do modelo processualista através da valorização da vontade das partes viabilizada pelos instrumentos processuais que permitem sua participação ativa.

A grande mudança não reside na mera admissibilidade de negociações sobre o processo - já que o CPC de 1973 já as contemplava, de forma típica (por exemplo, a inversão negocial do ônus da prova, prevista no seu art. 333, parágrafo único) -, mas sim na possibilidade de negócios atípicos (genéricos, portanto) sobre o processo. (TAVARES, 2016, p. 6) 
Desse modo, pelo fato de que é inerente à própria função social do processo a primazia da resolutividade do mérito, é dever não só do magistrado, mas também, e, principalmente, das partes, se posicionar cooperativamente, a fim de viabilizar um debate jurídico que proporcionasse ao julgador uma visão multifacetária do conflito, através dos pressupostos da boa-fé (objetiva e processual) e do respeito ao melhor interesse das partes (THIBAU; VIANA, 2017)

É justamente por isso que o processo civil atual prevê um modelo diverso daquele de cunho adversarial. Em suma, através da contratualização do processo é possível a adequação do procedimento às particularidades da causa através da participação ativa (e cooperativa) entre os sujeitos da relação jurídico-processual.

Assim, por meio de um processo cada vez mais democrático, se obtém a pacificação social em decorrência da maior aceitabilidade das decisões judiciais. Isso porque, a sentença proferida pelo magistrado num processo em que se permitiu adequação à realidade fática, passa a ser vista como produto da atuação das partes através dos negócios processuais que permitem um rito procedimental mais participativo.

Ainda que as disposições do CPC se dediquem mais aos direitos individuais, é inegável que este diploma construiu um verdadeiro microssistema de tutela coletiva de direitos e, a partir disso, alguns instrumentos processuais típicos daquela primeira esfera, também puderam ser aplicados quando da tutela de direitos difusos, coletivos e individuais homogêneos.

E mais, este é o primeiro Código que nasce pressupondo a tutela coletiva, incorporando uma boa parte de técnicas processuais apenas para o âmbito coletivo trazendo inúmeras inovações que podem aperfeiçoar bastante a tutela de direitos dessa categoria. (DIDIER Jr., ZANETI Jr., 2018, p. 20)

Esse microssistema coletivo subdivide um mesmo ordenamento jurídico em diversos segmentos independentes, porém, ao mesmo tempo, harmônicos entre si na medida em que cada centro de poder, mesmo possuindo disposições próprias, se submete às normas cogentes e obedece aos princípios gerais por elas estabelecidos.

Um dos principais aspectos do sistema processual coletivo brasileiro foi estabelecer os legitimados a tutelar judicialmente os direitos de classes e grupos. Acerca do tema, a doutrina prevê, de forma geral, três espécies de legitimação: ordinária, extraordinária e autônoma.

A principal diferença entre as duas primeiras reside no fato de que, na ordinária, se age em nome próprio, porém em defesa dos próprios interesses, já na extraordinária, se age em nome próprio a fim de defender interesse alheio. A autônoma, por sua vez, é basicamente uma modalidade distinta de substituição processual. 
A lei estabeleceu expressamente o rol dos legitimados à negociação e também seus parâmetros objetivos. Assim, são legitimados: o particular, através da ação popular; as pessoas jurídicas de direito privado, pelo mandado de segurança coletivo; e as pessoas jurídicas de direito público, por meio da ação civil pública.

Desse modo, como se trata de substituição processual, a tutela jurisdicional proveniente da atuação desses legitimados somente se opera sobre a esfera de direitos das pessoas ou coletividades substituídas no processo, e não da entidade que atua como substituto.

Vale lembrar que, no âmbito da representação, cada um destes entes responsáveis por figurar em juízo em nome de interesses de terceiros podem negociar processualmente da mesma forma que o próprio titula do direito, de forma individual, o faria. Isso traduz o respeito à própria operacionalidade do processo, uma vez que seria impraticável que todos os titulares individuais daquele direitos coletivos figurassem em juízo e decidissem acerca dos acordos processuais.

O principal obstáculo apontado seria a necessidade de a causa versar sobre direitos que admitam autocomposição. Contudo, o objeto do ajustamento entre as partes não é o direto material, mas sim as disposições processuais concernentes ao procedimento adotado o que pode ser objeto de transação entre os sujeitos. O negócio processual permite tão somente a modulação do procedimento judicial, de modo que o conteúdo do direito material tutelado por meio do processo em nada é interferido.

Assim, mesmo que o negócio processual traga consigo qualquer violação ao equilíbrio entre as partes ou que importe a qualquer uma delas prejuízo à tutela do direito material, posteriormente, quando do controle judicial da validade, será constatada qualquer possível violação ao devido processo legal.

Uma das principais questões acerca da aplicabilidade dos negócios processuais às ações coletivas se relaciona justamente com a legitimidade atribuída a determinados órgãos para atuar processualmente representando interesses da coletividade. Por isso, se discute como e quais os limites em que tais entes, devidamente autorizados por lei, atuam de modo a representar interesses difusos quando da realização dos acordos processuais.

Ocorre que, como as convenções processuais pretendem flexibilizar o procedimento de modo que se permita a adequada e efetiva tutela jurisdicional aos interesses materiais, os negócios servem de instrumento à pacificação social na medida em que harmonizam os interesses entre os envolvidos e é por isso que são plenamente possíveis os acordos para constituir, modificar ou extinguir situações processuais desde que respeitados os limites legalmente estabelecidos. 


\section{Limites à negociação processual coletiva}

\subsection{Momento processual ideal para negociar}

A evolução do sistema processual brasileiro com a possibilidade de superação do modelo individualista de processo através da tutela coletiva de direitos viabilizada pelo processo coletivo possibilitou maior efetividade na garantia desses direitos e, consequentemente, trouxe maior economia processual e acesso à justiça. (SILVESTRE; NEVES; GUSELLA, 2017)

A considerar que o negócio jurídico tem por objeto o comportamento das partes no processo ou as próprias normas processuais e não a pretensão jurídica da ação, acaba que a ampla possibilidade de celebração dos negócios atípicos depende (na medida da lei e de sua exequibilidade) somente da criatividade humana. Ou seja:

[...]a existência de conflito a respeito do direito material não implica necessariamente um desacordo das partes quanto às posições processuais, sendo perfeitamente possível uma comunhão de vontades sobre os meios de resolução do conflito. (TAVARES, 2016, p. 7)

Muito além da ordinária possibilidade de se negociar processualmente durante o processo (seja judicial seja extrajudicialmente) ou antes mesmo de sua existência, a convenção pode ser realizada com o intuito de sanear algum vício de procedimento ou, até mesmo, quando configurada a litispendência.

Acerca da litispendência, ainda que o art. 485, V do CPC traga como resultado a extinção, sem resolução de mérito, da ação proposta posteriormente, também há como resultado desse instituto a reunião dos processos para julgamento pelo mesmo juízo a fim de evitar decisões conflitantes, que é justamente o que ocorre nas ações coletivas.

De acordo com o art. 104 do CDC, ainda que a ação coletiva não induza litispendência para individual, a coisa julgada coletiva, apesar de não poder prejudicar os indivíduos, poderá beneficiá-los. (DIDIER Jr.; ZANETI Jr., 2018)

É aqui que se configura a possibilidade de negociação quando ocorre a litispendência: o autor da ação individual, desde que saiba inequivocamente da existência de processo coletivo com mesmo pedido ou causa de pedir, pode abdicar de sua posição jurídica de vantagem (beneficiar-se com a sentença coletiva) o que é feito mediante negociação atípica. Ou seja, a decisão pelo prosseguimento do processo individual a despeito do coletivo, é um negócio jurídico unilateral dispositivo tomado pela própria parte titular do direito. 
E, também, pode o autor da ação individual em litispendência com a coletiva requerer a suspensão de seu processo individual para que, após isso, possa se beneficiar com o resultado da coisa julgada coletiva.

\subsection{Negociação processual coletiva por meio de representação: os substitutos processuais}

A defesa de direitos individuais homogêneos (que decorrem de origem comum) é feita por entes legitimados para tanto. E, como produto da tutela coletiva de tais direitos que, em sua gênese, são individuais, se possibilita que todos os que se encontram em determinada situação sejam beneficiados com aquele resultado (VIEIRA, 1993).

Isso significa dizer que, a respeito de uma mesma situação danosa, podem coexistir interesses de titularidades distintas (tanto individuais quanto coletivas). Contudo, nada impede que um direito individualmente ofendido seja tutelado de forma coletiva pelo simples fato de que demonstrou lesão a interesses difusos.

O exercício do direito de ação se perfectibiliza pelo preenchimento das condições da ação: legitimidade e interesse de agir, ambas dispostas pelo artigo 17 do CPC. Enquanto que legitimidade é a aptidão para ocupar, em um certo caso concreto, uma posição processual ativa (CÂMARA, 2017, p. 44), o interesse de agir, se traduz pela necessidade da tutela jurisdicional e adequação da via eleita para tanto.

Para além das legitimidades ordinária, em que se defende em juízo direitos dos quais se é titular e extraordinária, em que se defende em juízo direitos dos quais um terceiro é titular, existe a ad causam, legitimidade autônoma em que não é possível se identificar o titular do direito discutido e, em decorrência disso, nem ele pode ir a juízo defendê-lo, nem pode atuar em defesa de interesse alheio.

Em se tratando da tutela coletiva de direitos, sempre haverá um ente que representará os interesses lesados de determinada categoria (ou de determinados sujeitos, quando direitos individuais homogêneos). Isso porque não é o próprio sujeito que figura em juízo para tutelar direito próprio, mas sim um terceiro que participará da relação jurídica tutelando direito do qual aquele sujeito é o titular.

O comportamento dos legitimados a atuar depende, principalmente, do que a própria legislação os permite fazer no âmbito da tutela de direitos coletivos. A título de exemplo, mesmo que igualmente legitimados a estar em juízo nas causas de natureza coletiva, o Ministério Público e a Defensoria Pública têm atuações diferentes.

Para Zavascki, aquele que atua como substituto processual (o ente ou a instituição devidamente autorizada por lei) não toma o lugar do titular na relação de direito material, já 
que não é ele o portador do direito. O que ocorre é tão somente a representação, em nome próprio, de um direito (material) do qual um terceiro é titular. Por isso, em sua atuação, o substituto processual jamais poderá dispor sobre o direito material do qual o substituinte é titular, pelo simples fato de aquele direito não ser seu.

É evidente que os limites para a substituição estão umbilicalmente ligados ao respeito à titularidade do direito material ali discutido. Ora, se o substituto não é o titular, jamais poderá dispor acerca do direito de outrem (isso no âmbito material).

Por outro lado, ainda que possa o representante dispor acerca das prerrogativas processuais, isso jamais pode atingir o direito material do qual o substituído é titular.

Portanto, sendo indisponível para o substituto processual o direito material objeto da demanda, fica igualmente fora dos seus poderes a prática de atos que, mesmo tendo natureza processual, podem, ainda que indiretamente, comprometer a higidez daquele direito. (ZAVASCKI, 2017, p. 70)

\subsection{Limites à legitimidade na negociação coletiva e os impactos à operacionalidade da negociação e do processo}

Através da cláusula geral de negociação, as condições para os acordos processuais foram estabelecidas e, com o privilégio à autonomia da vontade das partes, é possível que os negócios jurídicos processuais sejam celebrados de forma mais abrangente e criativa, justamente em sua modalidade atípica.

Ocorre que, mesmo sendo comprovada maior eficácia ao procedimento através da realização dessas convenções processuais, a legislação e até mesmo o controle judicial acabam por estabelecer alguns obstáculos tanto à operacionalidade da negociação quanto do próprio processo em si.

Nesse sentido, é preciso analisar se os limites estabelecidos à negociação atípica no âmbito do processo coletivo são legítimos ou se eles estão a impedir, muitas vezes, as garantias do processo e consequentemente a maior eficácia no caminho à resolução do mérito.

A considerar que uma das maiores pretensões do CPC é a promoção de uma solução não só mais rápida, mas também mais satisfatória aos litígios, melhor alternativa não há senão a efetivação do princípio da cooperação através da abertura de um espaço ideal para a participação das partes na construção do procedimento. Para tanto, a ferramenta da negociação processual atípica permite aos sujeitos processuais um desenvolvimento mais democrático do procedimento na medida em que somente se celebram acordos quando houver igualdade de condições entre as partes. (NERY Jr.; NERY, 2015) 
É justamente por acreditar que um bom acordo processual é aquele que respeita as diferentes necessidades das partes e busca, através da ponderação, proporcionar um resultado satisfatório a ambas por meio da cooperação entre elas, que se entende desproporcional e impositiva a restrição legal acerca da possibilidade de realização de negócios tão somente quando se tratar de direitos que admitam autocomposição.

Além do mais, se considera que tal limitação legal é um tanto quanto abusiva pelo fato de que a indisponibilidade de um direito não se confunde com a possibilidade de sua autocomposição. Há casos em que, não obstante a indisponibilidade do direito material, há aspectos que admitem autocomposição (CÂMARA, 2017, p. 116).

Inclusive, segue esse mesmo raciocínio o Enunciado 135 do FPPC: “A indisponibilidade do direito material não impede, por si só, a celebração de negócio jurídico processual."

Ora, se a indisponibilidade do direito fosse um óbice à negociação, jamais um legitimado extraordinário (que não é titular do direito material) poderia celebrar negócio processual a considerar que indisponível a ele o direito do terceiro que está em juízo representando.

O que se pretende defendendo a realização de negócios processuais atípicos no âmbito do processo coletivo é a efetivação do que Mancuso defende como sobreprincípio do ordenamento jurídico brasileiro: o devido processo legal. A transcendência e relevância desse mandamento possui, inclusive, amparo constitucional nos incisos $\mathrm{LIV}^{4} \mathrm{e} \mathrm{LV}^{5}$ do art. $5^{\circ}$ da CRFB/88. (MANCUSO, 2018)

De acordo com Nery Jr. e Nery, tal princípio é a base sobre a qual todos os outros se sustentam e é justamente por isso que o devido processo legal é um gênero de princípio do qual todos os demais são espécies. Portanto, em qualquer espécie de procedimento, tal mandamento merece pleno respeito e, de igual valia, suas disposições decorrentes (o contraditório e a ampla defesa).

Por isso que a observância desses princípios legitima o próprio procedimento que deixa de ser um rito engessado e passa a privilegiar, também, a vontade das partes. Ora, um processo devido é aquele que deve respeito não só aos limites legais, mas também à autonomia privada.

Desse modo, a negociação atípica - mais ampla e criativa - no processo que tutela direitos coletivos viabiliza um procedimento mais democrático e comparticipativo na medida em que cria uma simetria entre as características do caso concreto e a cognição judicial sem,

\footnotetext{
${ }^{4}$ LIV - ninguém será privado da liberdade ou de seus bens sem o devido processo legal;

${ }^{5} \mathrm{LV}$ - aos litigantes, em processo judicial ou administrativo, e aos acusados em geral são assegurados o contraditório e ampla defesa, com os meios e recursos a ela inerentes;
} 
necessariamente, se esgotar por completo a matéria de fato e de direito, o que geraria per si um rito distendido. (MANCUSO, 2018, p. 83)

Além do mais, a própria gestão do processo está em jogo quando se trata dos acordos processuais. Isso porque o juiz é aquele que aplica o ordenamento de modo a dirigir o processo para uma resolução do mérito de forma mais eficiente (CAMPOS, 2017), sendo os negócios processuais ferramentas à execução desse dever de gestão.

A verdade é que, por ser um dever, a gestão processual se relaciona diretamente com o interesse público uma vez que o processo é instrumento que serve à coletividade, ante ao princípio da inafastabilidade da jurisdição (art. 5, XXXV CRFB/88). Por tal motivo, ao gerir o processo, cabe ao juiz alocar os recursos a ele disponíveis a fim de não só obter a resolução do mérito, mas fazê-la de forma eficiente através do resguardo às garantias fundamentais do devido processo legal.

O juiz não é o único protagonista da gestão do processo judicial. Como visto, as partes também podem gerir o procedimento pela celebração de negócios processuais (CAMPOS, 2017, p. 140). Por isso, quando da celebração desses acordos, também devem os sujeitos respeitar o devido processo legal e as demais garantias do processo já que igualmente titulares do dever de gestão, ainda que submetidos ao controle de validade por parte do magistrado.

$\mathrm{Na}$ verdade, a defesa pela possibilidade de se negociar de modo a priorizar - e por que não legitimar - a autonomia da vontade das partes através da negociação atípica no âmbito do processo coletivo é no sentido de viabilizar aquilo que o próprio CPC pretende: a democratização do procedimento por meio da cooperação.

Como resultado disso, a resolução do mérito se dará de modo muito mais eficiente na medida em que as próprias partes (ainda que por meio de legitimados extraordinários) guiarão o procedimento às especificidades da causa e, consequentemente, do direito que pretendem por ela ver tutelado.

\section{CONSIDERAÇÕES FINAIS}

Este artigo teve por finalidade discutir o problema dos limites à negociação processual atípica no âmbito do processo coletivo, do momento processual ideal para se negociar e da amplitude da legitimidade à negociação no âmbito do processo coletivo e, consequentemente, da tutela coletiva de direitos.

Com base nisso, por serem os negócios atípicos uma modalidade de convenção que permite maior criatividade às partes já que sua forma não é prevista por lei (tão somente suas 
disposições gerais o são), se acredita ser essa a espécie mais eficaz quando da tutela coletiva de direitos.

Ainda que exista uma cláusula geral de negociação a ser seguida a finalidade dos negócios processuais é a flexibilização do procedimento. Assim, as partes, de forma cooperativa, podem construir um modelo ideal de procedimento adequado às especificidades da causa em que figuram.

Tudo isso demonstra a evolução do próprio processo civil que, hoje em dia, prioriza a resolutividade de mérito da forma mais eficaz possível.

Justamente por priorizar a autonomia da vontade, a regra para a celebração dos negócios processuais é a desnecessidade de homologação deles, somente em casos excepcionais previstos em lei quando for condição de eficácia do próprio negócio.

Desse modo, se enxerga a possibilidade de negociar processualmente como uma forma de concretização dos princípios presentes do novo CPC e, consequentemente, de garantir maior efetividade e eficiência na condução do processo judicial através do incentivo à composição entre os sujeitos em contraponto ao sistema adversarial de processo.

É nesse sentido que se pretende a realização de negócios atípicos no âmbito da tutela coletiva: para possibilitar a efetivação de um modelo cooperativo e comparticipativo de processo inaugurado pelo novo CPC de 2015 para, com isso, ser possível modular o procedimento às especificidades de cada causa independentemente da natureza do direito que está sendo discutido.

Quando da tutela coletiva de direitos, os legitimados a representar processualmente os interesses difusos também estão autorizados à negociação processual. Inclusive, isso contribui com a própria operacionalidade do processo, já que seria impraticável que todos os titulares individuais daquele direito coletivo figurassem em juízo para a celebração de acordos processuais.

O principal objetivo do processo coletivo é o de garantir, de forma eficaz e efetiva, a prestação jurisdicional às coletividades através de instrumentos capazes de suprir os interesses dos titulares daquele direito difuso.

É por entender que as garantias do devido processo legal merecem ser respeitadas (e priorizadas) que se defende a realização de negócios processuais atípicos nas ações coletivas. Tal prerrogativa valoriza a autonomia da vontade das partes, ainda que quem figure em juízo seja um legitimado extraordinário.

$\mathrm{Na}$ defesa dos direitos coletivos, também é possível que figurem em juízo os substitutos processuais. Esses não substituem o titular na relação de direito material, já que não são eles os 
portadores, somente atuam em nome próprio na defesa de um direito material do qual um terceiro é o titular.

Contudo, jamais se confundem os institutos da substituição processual e o da legitimidade autônoma pelo fato de que os efeitos da coisa julgada são diferentes quando do processo individual e do coletivo. Como não pode um substituto atuar para representar sujeitos indeterminados, é preciso que o direito seja de natureza individual para que tal figura seja mais eficaz. Por outro lado, na legitimação autônoma, a própria lei autoriza órgão ou ente para atuar em juízo na defesa de direito do qual a coletividade é titular, assim, não se individualizam os sujeitos de direito.

O que se defende, porém, é a possibilidade de realização de acordos processuais por substitutos mesmo nas ações que tratem de direitos individuais homogêneos e por legitimados autônomos nas ações coletivas (para representação de direitos difusos e coletivos) tudo isso para se obter maior eficiência ao procedimento e celeridade na prestação jurisdicional do mérito.

Assim, o CPC inaugura um novo paradigma na medida em que transforma o modelo processualista através da valorização da vontade das partes, com a permissibilidade para a celebração de negócios processuais por meio da participação ativa dos sujeitos que compõem a relação jurídico-processual.

É justamente por se acreditar que um bom acordo processual é aquele que respeita as diferentes necessidades das partes e busca, pela ponderação, proporcionar um resultado satisfatório a ambas através da cooperação entre elas, que se defende a negociação processual atípica como modalidade criativa de acordo processual - sobretudo nas demandas coletivas com o intuito de proporcionar a efetivação do devido processo legal, da cooperação e da celeridade.

\section{REFERÊNCIAS}

BRASIL. Lei n. 13.105, de março de 2015. Código de Processo Civil. Brasília: Senado Federal, Secretaria de Editoração e Publicações. Disponível em: <http://www2.senado.gov.br/bdsf/handle/id/507525 >. Acesso em 23 de julho de 2019.

BRASIL. Constituição da República Federativa do Brasil de 1988. Brasília: Senado Federal: Centro Gráfico, $1988 . \quad$ Disponível em: http://www.planalto.gov.br/ccivil_03/constituicao/constituicaocompilado.htm>. Acesso em: 18/06/2019. 
BRASIL. Informativo de Jurisprudência do Supremo Tribunal Federal. Brasília: Supremo Tribunal Federal. 25 a 29 de fevereiro de 2008. n. 496. Disponível em: < http://www.stf.jus.br/arquivo/informativo/documento/informativo496.htm>. Acesso em 29/07/2019.

BUENO, Cassio Scarpinella. Manual de direito processual civil: volume único. 4. ed. São Paulo: Editora Saraiva, 2018.

BUENO, Cassio Scarpinella. Novo Código de Processo Civil Anotado. 3. ed. São Paulo: Editora Saraiva, 2017.

CÂMARA, Alexandre Freitas. O novo processo civil brasileiro. 3. ed. São Paulo: Editora Atlas, 2017.

CAMPOS, Eduardo Luiz Cavalcanti. O princípio da eficiência no processo civil brasileiro. 2017. Dissertação (Mestrado em Direito Processual Civil) - Universidade Federal de Pernambuco, Recife.

DIDIER Jr., Fredie. Curso de Direito Processual Civil: introdução ao direito processual civil, parte geral e processo de conhecimento.19. ed. Salvador: Editora JusPodivm, 2017.

DIDIER Jr., Fredie. Ensaios sobre os negócios processuais. Salvador: Editora JusPodivm, 2018.

DIDIER Jr, Fredie; ZANETI Jr. Hermes. Curso de direito processual civil: processo coletivo. 12. ed. v. 4. Salvador: Editora JusPodivm, 2018.

DIDIER Jr. Fredie; NOGUEIRA, Pedro Henrique Pedrosa. Teoria dos fatos processuais. 2. ed. Salvador: Editora JusPodivm, 2012.

ENFAM. Escola Nacional de Formação e Aperfeiçoamento de Magistrados. Enunciados. Disponível em: <https://www.enfam.jus.br/wp-content/uploads/2015/09/ENUNCIADOSVERS\%C3\%83O-DEFINITIVA-.pdf $\geq$. Acesso em 18/06/2019.

GUERRA, Rogéria Gladys Sales. Globalização E Direito Do Trabalho: Principais Desafios. Revista Jurídica, [S.1.], v. 2, n. 39, p. 173 - 193, jan. 2016. ISSN 2316-753X. Disponível em: 〈http://revista.unicuritiba.edu.br/index.php/RevJur/article/view/1313/880>. Acesso em: 23 abr. 2020. doi:http://dx.doi.org/10.21902/revistajur.2316-753X.v2i39.1313. 
MANCUSO, Rodolfo de Camargo. Teoria geral do processo. 1. ed. Rio de Janeiro: Editora Forense, 2018.

MARINONI, Luiz Guilherme; ARENHART, Sérgio Cruz; MITIDEIRO, Daniel. Novo curso de processo civil: tutela dos direitos mediante procedimentos diferenciados. 3. ed. v. 3. São Paulo: Editora Revista dos Tribunais, 2017.

MEDINA, José Miguel Garcia. Direito Processual Civil Moderno. 3. ed. rev., atual. e ampl. São Paulo: Editora Revista dos Tribunais, 2017.

NEVES, Daniel Amorim Assumpção. Novo Código de Processo Civil Comentado Artigo por Artigo. 2. ed. rev. e atual. Salvador: Editora JusPodivm, 2017.

NERY JR, Nelson; NERY, Rosa Maria de Andrade. Comentários ao Novo Código de Processo Civil. 1. Ed. São Paulo: Editora Revista dos Tribunais, 2015.

SILVESTRE, Gilberto Fachetti; NEVES, Guilherme Valli de Moraes; GUSELLA, Gabriela Azeredo. Tutela Processual Coletiva: os impactos e novidades do novo Código de Processo Civil. In: O labirinto da codificação do Direito Internacional Privado. Vitória: Anais do II Congresso de Processo Civil Internacional, p. 303-319, 2017.

TAVARES, João Paulo Lordelo Guimarães. Da admissibilidade dos negócios jurídicos processuais no novo código de processo civil: aspectos teóricos e práticos. Teoria Geral do Processo. Revista de Processo. São Paulo: Editora Revista dos Tribunais. v. 254, abr. 2016.

THEODORO JÚNIOR, Humberto. Curso de Direito Processual Civil. Teoria geral do direito processual civil, processo de conhecimento e procedimento comum. 58. ed. rev., atual. e ampl. v. 1. Rio de Janeiro: Editora Forense, 2017.

THIBAU, Tereza Cristina Sorice Baracho; VIANA, Thaís Costa Teixeira. Negócios jurídicos processuais e a modulação do procedimento nas ações coletivas. Revista de Processo, Jurisdição e Efetividade da Justiça. Brasília. v. 3. n. 1, p. 75-96, jan./jun. 2017.

VIEIRA, Fernando Grella. A transação da esfera da tutela dos interesses difusos e coletivos e a posição do Ministério Público. Doutrina. São Paulo: Editora Justitia, v. 55, n. 161, p. 4053, jan./mar., 1993.

ZAVASCKI, Teori Albino. Processo coletivo: tutela de direitos coletivos e tutela coletiva de direitos. 7. ed. rev., atual. e ampl. São Paulo: Editora Revista dos Tribunais, 2017. 